\title{
PENYULUHAN DAN PELATIHAN PEMBUATAN HAND SANITIZER DI DESA TAMBAKBAYA KOTA GARUT SEBAGAI LANGKAH PENCEGAHAN COVID 19
}

\author{
Asman Sadino $^{1^{*}}$, Riza Apriani ${ }^{2}$, Agustine Chandra Suryana ${ }^{3}$, Arief \\ Rakhmatuloh $^{4}$, Aning Suryani ${ }^{5}$, Widi Mahrunnisa Pratiwi ${ }^{6}$ \\ ${ }^{13456}$ Program Studi Farmasi, Fakultas Matematika dan Ilmu Pengetahuan Alam, \\ Universitas Garut, Jawa Barat \\ ${ }^{2}$ Program Studi Kimia, Fakultas Matematika dan Ilmu Pengetahuan Alam, \\ Universitas Garut, Jawa Barat \\ "Email korespondensi: asman@uniga.ac.id
}

Disubmit: 03 November $2021 \quad$ Diterima: 12 Desember $2021 \quad$ Diterbitkan: 02 Januari 2022 DOI: https://doi.org/10.33024/jkpm.v1i1.5409

\begin{abstract}
ABSTRAK
Pandemi Covid-19 yang terjadi saat ini beberapa waktu yang lalu menyebabkan kelangkaan hand sanitizer dipasaran, hal ini membuat resah sebagian masyarakat. Pembuatan hand sanitizer yang dibuat dengan komposisi yang kurang tepat maka efektivitas hand sanitizer dalam membunuh bakteri dan virus tentunya akan berkurang. Pemanfaatan bahan alam sebagai bahan alternatif dalam pembuatan hand sanitizer. Diketahui beberapa tanaman yang memiliki kemampuan daya hambat terhadap bakteri yang bisa digunakan sebagai zat aktif maupun zat tambahan di dalam produksi hand sanitizer salah satunya adalah lidah buaya. Tujuan dari kegiatan pengabdian ini adalah menghasilkan suatu produk kesehatan yang dapat dimanfaatkan baik untuk diri sendiri, keluarga dan masyarakat sekitar dalam rangka untuk mencegah penyebaran virus Covid-19. Metode yang digunakan dengan memberi penjelasan kegunaan dan keunggulan sediaan hand sanitizer yang terbuat dari bahan alami yaitu lidah buaya (Aloe vera) melalui video dan pamflet. Hasil dari kegiatan pengabdian kepada masyarakat ini dinilai dapat memberikan dampak positif kepada masyarakat Desa tambakbaya, Kecamatan Cisurupan, Kabupaten Garut dilihat dari antusiasme masyarakat Desa dalam menerima pamflet dan video sebagai sumber informasi yang sangat bermanfaat bagi mereka dalam membuat hand sanitizer berbahan dasar alami (Aloe vera) sehingga bisa dirasakan manfaatnya. Kerjasama antara kepala Desa dan aparatur Desa harus terus ditingkatkan agar dampak positif dapat menjadi dampak berkelanjutan.
\end{abstract}

Kata Kunci: Hand sanitizer, antiseptik alami, aloe vera, pencegahan virus corona

\section{ABSTRACT}

The Covid-19 pandemic that occurred some time ago caused the scarcity of hand sanitizers in the market, this made some people nervous. Making hand sanitizers that are made with inappropriate compositions will reduce the effectiveness of hand sanitizers in killing bacteria and viruses. Utilization of natural materials as alternative materials in making hand sanitizers. It is known that several plants can inhibit bacteria which can be used as active substances or additives in the production of hand sanitizers, one of which is aloe vera. The purpose of this service activity is to produce a health product that can be used for both 
yourself, family, and the surrounding community to prevent the spread of the Covid-19 virus. The method used is to explain the uses and advantages of hand sanitizer preparations made from natural ingredients, namely aloe vera (Aloe vera) through videos and pamphlets. The results of this community service activity are considered to have a positive impact on the people of Tambakbaya Village, Cisurupan District, Garut Regency, seen from the enthusiasm of the Village community in receiving pamphlets and videos as a source of information that is very useful for them in making hand sanitizers made from natural ingredients (Aloe vera) so that the benefits can be felt. Cooperation between the village head and village officials must be continuously improved so that positive impacts can become sustainable impacts.

Keywords : Hand sanitizer, natural antiseptic, aloe vera, corona virus prevention

\section{PENDAHULUAN}

Situasi pandemi akibat virus Covid-19 selama dua tahun ini telah membiasakan masyarakat Indonesia untuk menjaga pola hidup bersih. Membawa hand sanitizer adalah sebuah kebiasaan baru yang muncul sebagai upaya mencegah terpaparnya tubuh dari virus tersebut ketika berada di luar rumah (Sadino 2021)

Pandemi Covid-19 yang terjadi saat ini beberapa waktu yang lalu menyebabkan kelangkaan hand sanitizer dipasaran, hal ini membuat resah sebagian masyarakat (Handoyo 2020). Hand sanitizer digunakan untuk menjaga kebersihan tangan sehingga meminimalisir penularan virus dan bakteri. Penggunaannya yang simple dan mudah untuk dibawa-bawa sehingga menjadi daya tarik utama dari hand sanitizer (Walidah, Supriyanta et al. 2014). Namun saat ini jumlah hand sanitizer di pasaran sangat terbatas dan harganya mahal dibandingkan sebelum terjadi pandemi Covid-19. Inilah alasan sebagian masyarakat akhirnya memilih memproduksi hand sanitizer sendiri. Namun, pembuatan hand sanitizer yang dibuat dengan komposisi yang kurang tepat maka efektivitas hand sanitizer dalam membunuh bakteri dan virus tentunya akan berkurang.

Beberapa sediaan hand sanitizer dapat dijumpai di pasaran dengan cara pemakaiannya cukup sederhana dan cepat. Namun biasanya banyak mengandung alkohol dan antiseptik berupa bahan kimia sintetis yang harganya relatif mahal dan sering menimbul masalah kesehatan kulit, misalnya kulit menjadi kering (terjadi penurunan kelembapan kulit normal) (Lestari and Pahriyani 2020). Oleh karena itu perlu dicari antiseptik dari bahan alam yang relatif lebih murah, aman, efektif, dan mudah didapat. Indonesia merupakan negara tropis yang kaya tanaman berkhasiat, maka dimungkinkan untuk mencari senyawa alternatif pengganti alkohol tersebut dari tanaman yang mudah dijumpai di Indonesia. Aktivitas antibakteri tanaman diperoleh dari kemampuan untuk mensintesis sekunder metabolit dan senyawa turunannya yaitu gugus fenolik, terpenoid, alkaloid, tanin, dan lain sebagainya (Sadino 2018). Salah satu tanaman tersebut adalah lidah buaya (Aloe vera).

Lidah buaya (Aloe vera) merupakan salah satu tanaman obat tradisional yang termasuk dalam suku Liliaceae, yang sering ditanam dipot atau halaman rumah. Namun, tanaman ini memiliki berbagai aktivitas farmakologi seperti antibakteri, antikanker, antivirus, dan antiinflamasi (Handayani 2019). Tanaman ini sudah dikenal luas oleh masyarakat Indonesia, umumnya digunakan sebagai bahan 
kosmetik, bahan makanan, perawatan kulit, penyembuhan luka hingga penyubur rambut. Aktivitas farmakologi tersebut bisa terjadi karena adanya kandungan senyawa kimia yang terkandung dalam lidah buaya (Aloe vera), kandungan senyawa kimia tersebut diantaranya antraquinone, tannin, polysaccharide, flavonoid dan saponin yang berfungsi sebagai antibakteri (Rahardjo, Koendhori et al. 2017).

Berdasarkan hal tersebut di atas, melalui program Kuliah Kerja Nyata (KKN) Universitas Garut menjadi salah satu langkah terobosan dalam rangka menekan penyebaran virus Covid-19 dengan cara memberikan sosialisasi pembuatan hand sanitizer dari bahan tumbuhan (alami) tidak sulit dan tidak membutuhkan biaya yang mahal dengan bahan dan peralatan yang dibutuhkan sangat sederhana, sehingga dapat diproduksi sendiri, di samping itu tumbuhan yang dibutuhkan untuk keperluan pembuatan hand sanitizer ini dapat dibudidayakan di pekarangan rumah (Fatimah and Ardiani 2018). Tujuan dari kegiatan pengabdian ini adalah menghasilkan suatu produk kesehatan yang dapat dimanfaatkan baik untuk diri sendiri, keluarga dan masyarakat sekitar dalam rangka untuk mencegah penyebaran virus Covid-19.

\section{MASALAH}

Sejak masuknya virus corona di Indonesia, masyarakat dituntut untuk melindungi diri sendiri dengan menggunakan masker, hand sanitizer, hingga rutin mencuci tangan. Hal ini dilakukan untuk pencegahan yang dimulai dari diri sendiri. Merebaknya virus corona di Indonesia menyebabkan kelangkaan akan masker dan hand sanitizer. Banyak orang berbondong-bondong menghabiskan stok masker dan hand sanitizer yang dijual di minimarket hingga supermarket. Hal ini menyebabkan lonjakan harga yang begitu tinggi, juga menyebabkan kelangkaan akan kebutuhan untuk memakai masker dan hand sanitizer. Inilah alasan sebagian masyarakat akhirnya memilih memproduksi hand sanitizer sendiri. Tentunya, hand sanitizer berbahan alami menjadi solusi yang tepat bagi kebiasaan mencuci tangan karena menggunakan bahan alami yang baik untuk kulit dan ramah lingkungan.

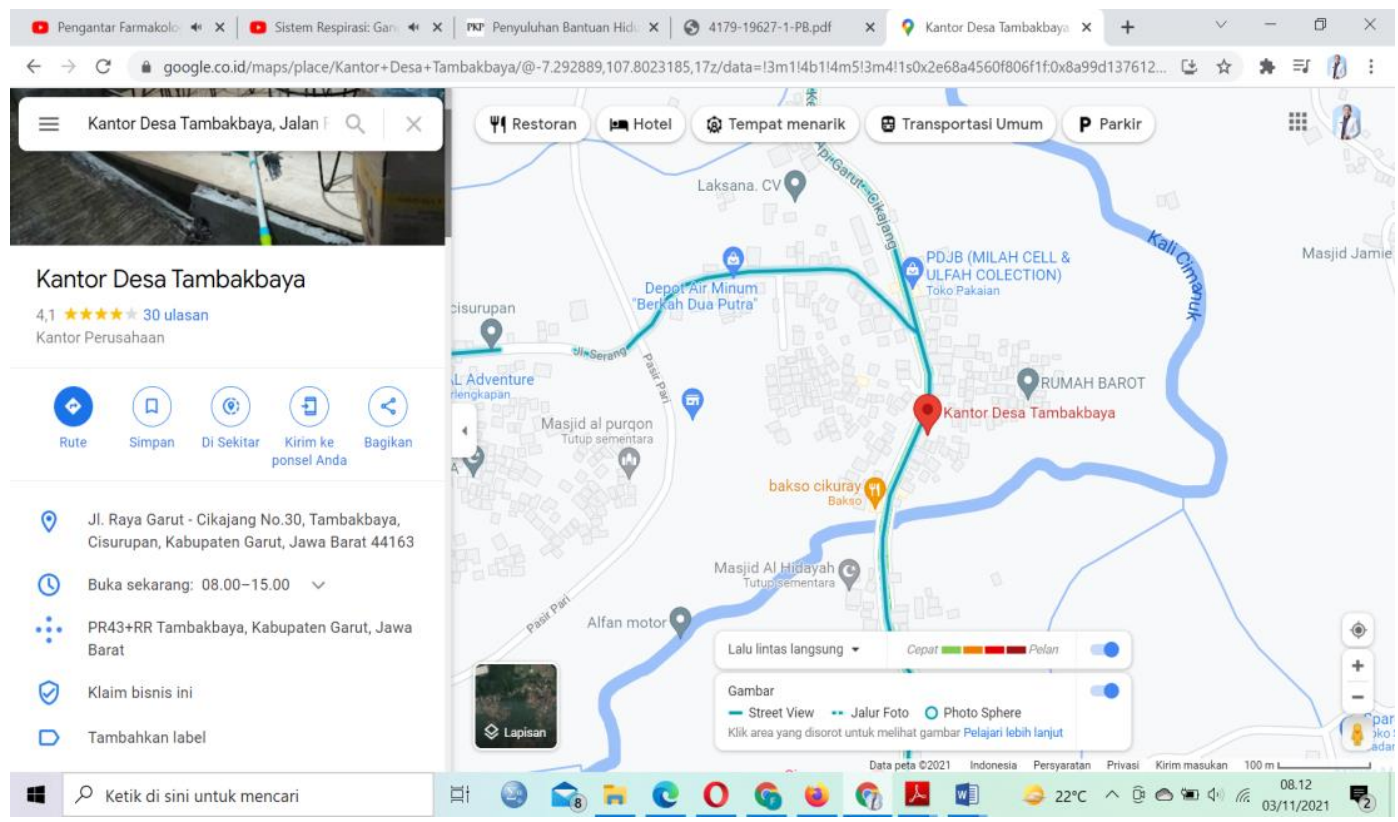

Gambar 2.1 Peta Lokasi Kegiatan Pengabdian Kepada Masyarakat. 


\section{METODE}

Kegiatan pengabdian kepada masyarakat ini dilaksanakan di Desa Tambakbaya, Kecamatan Cisurupan, Kabupaten Garut, Provinsi Jawa Barat. Pelaksanaan pengabdian kepada masyarakat ini dilakukan pada tanggal 09 Agustus 2020 yang terdiri dari beberapa tahapan sebagai berikut:

1. Memberi penjelasan kegunaan dan keunggulan sediaan hand sanitizer yang terbuat dari bahan alami yaitu lidah buaya (Aloe vera) melalui video dan pamflet. Menjelaskan cara-cara pembuatan sediaan hand sanitizer menggunakan alat-alat yang murah dan sederhana. Adapun alat dan bahan yang digunakan dalam pembuatan hand sanitizer sebagai berikut:
a. Lidah buaya
$50 \mathrm{ml}$
b. Alkohol $70 \%$
$40 \mathrm{ml}$
c. Bunga Jeruk Bali
secukupnya (sebagai pengaroma)
d. Blender
e. Sendok
f. Pisau
g. Saringan
h. Mangkuk
i. Baskom
j. Botol semprot
k. Botol kaca

2. Metode pelaksanaan pengabdian kepada masyarakat ini dengan cara mendokumentasikan cara pembuatan hand sanitizer dalam bentuk video dan nantinya video tersebut dikirimkan ke beberapa warga masyarakat Desa Tambakbaya. Isi video tersebut adalah bagaimana cara pembuatan hand sanitizer sebagai berikut:
a. Siapkan alat dan bahan
b. Cuci alat dan bahan
c. Rendam bunga jeruk bali dengan alkohol selama $1 \times 24$ jam didalam botol kaca
d. Ambil daging lidah buaya dan blender hingga halus
e. Daging lidah buaya yang sudah halus kemudian disaring
f. Campurkan lidah buaya yang telah disaring dengan bunga yang telah diekstrak dengan alkohol kedalam suatu wadah, aduk hingga tercampur rata
g. Masukkan campuran kedalam botol semprot
h. Hand sanitizer siap digunakan

Tahap evaluasi pelaksanaan program di lapangan setelah kegiatan ini selesai dilaksanakan adalah dengan terus membangun komunikasi dan dan memberikan informasi-informasi yang penting dengan Masyarakat dan juga Kepala Desa Tambakbaya, Kecamatan Cisurupan, Kabupaten Garut, Provinsi Jawa Barat.

\section{HASIL DAN PEMBAHASAN}

Mengantisipasi penyebaran virus corona, tim KKN Desa Tambakbaya Kelompok 3 Universitas Garut melakukan sosialisasi pembuatan hand sanitizer untuk digunakan masyarakat Desa Tambakbaya. Program ini terlaksana sebagai bentuk sumbangsih kepada masyarakat akibat langka dan melonjaknya harga cairan antiseptik berupa hand sanitizer di pasaran semenjak pandemi Covid-19 ini. Menjaga kebersihan diri dan mencuci tangan teratur menggunakan cairan 
antiseptik yang mengandung alkohol adalah salah satu upaya mencegah penularan Covid-19 (Larasati and Haribowo 2020).

Hal inilah yang menjadi alasan tim KKN Desa Tambakbaya Kelompok 3 yang setiap anggotanya berasal dari Jurusan Farmasi Fakultas Matematika dan IImu Pengetahuan Alam Universitas Garut akan melakukan sosialisasi pembuatan hand sanitizer. Hambatan yang ditemui pada saat sosialisasi adalah pada awalnya sosialisasi ini akan dilakukan kepada semua masyarakat di Desa Tambakbaya. Namun, karena kebijakan Pemerintah dalam menekan angka penularan covid-19 yang tidak memperbolehkan masyarakat berkumpul lebih dari 10 orang sehingga menyebabkan sasaran pelaksanaan menjadi berubah. Atas masukkan dari dosen pembimbing $\mathrm{KKN}$, maka kami mendokumentasikan cara pembuatan hand sanitizer tersebut dalam bentuk video dan nantinya video tersebut dikirimkan ke beberapa warga masyarakat Desa Tambakbaya. Melalui video tersebut diharapkan dapat membantu masyarakat desa Tambakbaya untuk nantinya dapat memproduksi hand sanititizer sendiri.

Isi video yang kami buat tersebut berisi proses pembuatan hand sanitizer yang kami lakukan menggunakan peralatan dan bahan yang sangat sederhana. Peralatan dan bahan yang digunakan dapat dilihat pada Gambar 1 dan Gambar 2. Setelah proses pembuatan hand sanitizer selesai kemudian kami memberikan hand sanitizer kepada masyarakat Desa Tambakbaya secara door to door sehingga masyarakat dapat langsung menggunakan produk yang telah kami buat sehingga bisa dirasakan manfaatnya, dapat dilihat pada Gambar 3 dan 4. Selain itu produk yang telah dibuat dikemas dalam bentuk sederhana. Hal ini sesuai dengan luaran yang diharapkan yakni berupa produk yang dapat dibuat dengan cara sederhana dan

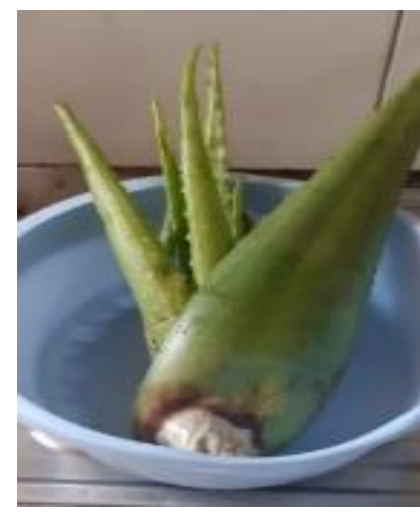

cukup murah.

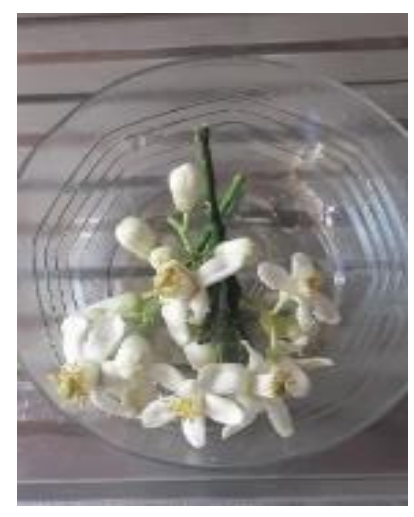

dengan biaya yang

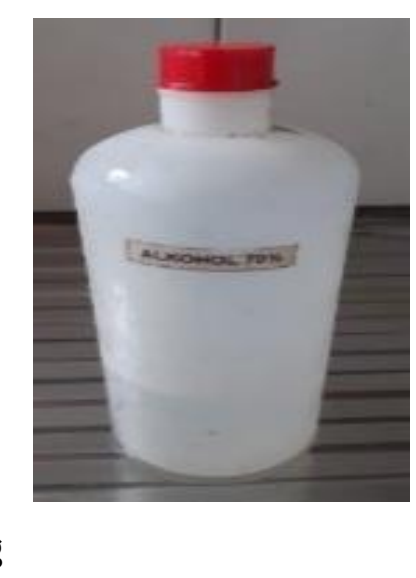

(c)

(a)

Gambar 2.2 Bahan yang digunakan alcohol

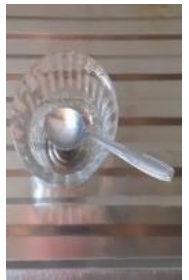

(a)

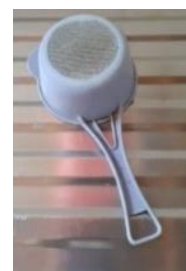

(b)

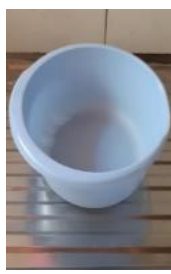

(c) (b) 
Gambar 2.3 Alat yang digunakan (a) saringan, (b) sendok, (c) baskom), (d) blender, (e) gelas ukur, (f) pisau, (g) botol semprot
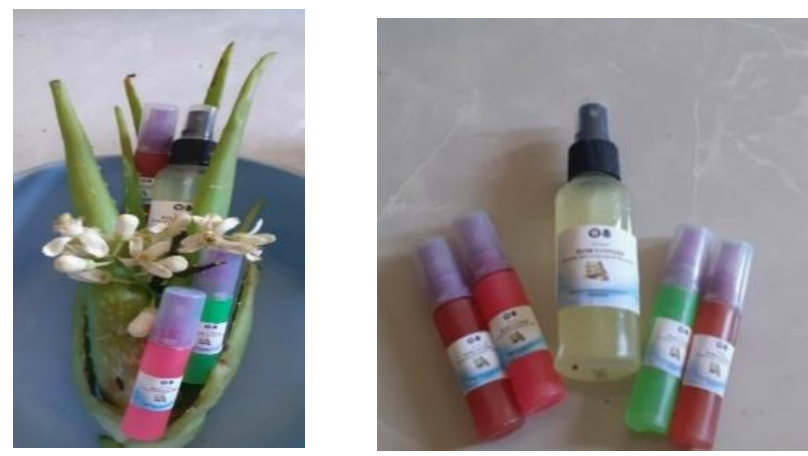

Gambar 2.4 Produk hand sanitizer yang telah dibuat oleh Tim Pengmas Desa Tambakbaya
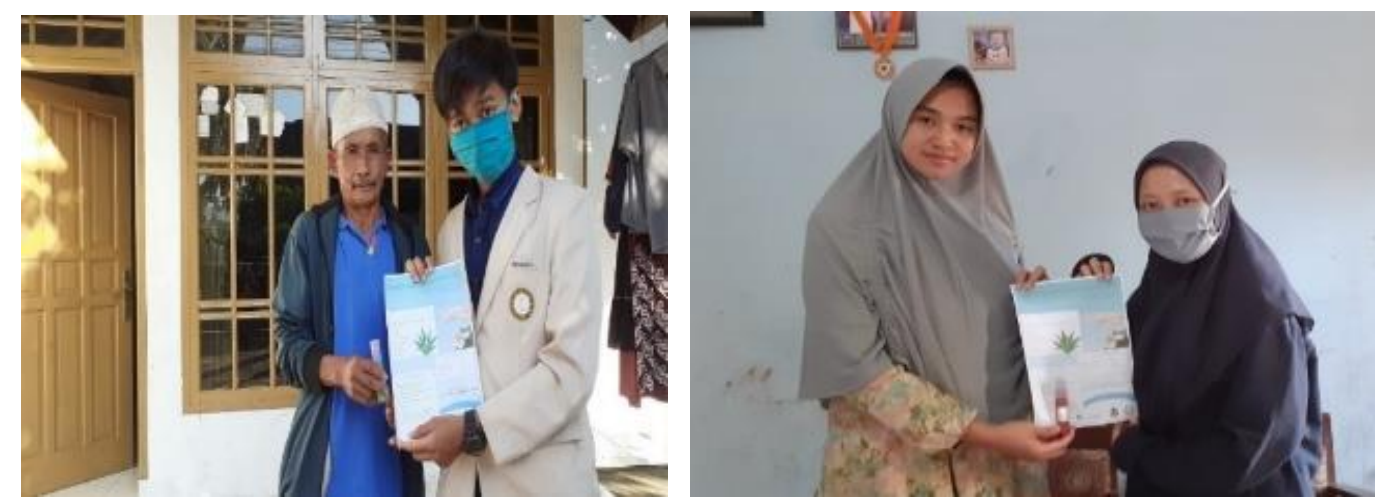

Gambar 2.5 Pemberian hand sanitizer dan pamflet kepada masyarakat Desa Tambakbaya

Pemanfaatan bahan alam sebagai bahan alternatif dalam pembuatan hand sanitizer. Diketahui beberapa tanaman yang memiliki kemampuan daya hambat terhadap bakteri yang bisa digunakan sebagai zat aktif maupun zat tambahan di dalam produksi hand sanitizer salah satunya adalah lidah buaya (Kurniadi 2020). Lidah buaya membantu menyembuhkan luka, lidah buaya mengandung senyawa glukomanan yakni senyawa yang memicu pertumbuhan sel kulit, membantu kulit membentuk kolagen, mengurangi peradangan dan melembabkan kulit (Azmi 2019) ; (Novyana and Susianti 2016).

Keberlanjutan program ini akan menciptakan masyarakat peduli akan kesehatan dan membantu program pemerintah sebagai upaya untuk saling peduli dan bekerjasama untuk pencegahan Covid-19 (Syapitri 2020). Selain itu, beberapa masyarakat yang berpendapat agar program ini di sosialisasikan dan sebarluaskan kepada masyarakat sekitar agar masyarakat yang lain mengetahui juga cara pembuatan hand sanitizer dari pemanfaatan bahan alami.

\section{KESIMPULAN}

Hasil dari kegiatan pengabdian kepada masyarakat ini dinilai dapat memberikan dampak positif kepada masyarakat Desa tambakbaya, Kecamatan Cisurupan, Kabupaten Garut dilihat dari antusiasme masyarakat Desa dalam menerima pamflet dan video sebagai sumber informasi yang sangat bermanfaat 
bagi mereka dalam membuat hand sanitizer berbahan dasar alami (Aloe vera) sehingga bisa dirasakan manfaatnya. Kerjasama antara kepala Desa dan aparatur Desa harus terus ditingkatkan agar dampak positif dapat menjadi dampak berkelanjutan.

\section{DAFTAR PUSTAKA}

Azmi, N. (2019). Efektifkah Menggunakan Lidah Buaya untuk Mengobati Luka. [internet]. [diakses pada tanggal 4 September 2020]. Tersedia pada: https://hellosehat.com/hidup-sehat/pertolongan-pertama/lidah-buayauntuk-luka/\#gref

Fatimah, C. and R. Ardiani (2018). Pembuatan hand sanitizer (pembersih tangan tanpa air) menggunakan antiseptik bahan alami. Prosiding Seminar Nasional Hasil Pengabdian.

Handayani, G. N. (2019). Uji Aktivitas Ekstrak Etanol Daun Lidah Buaya (Aloe Vera) Terhadap Penghambatan Pertumbuhan Staphylococcus aureus Dan Candida albicans. Biosel: Biology Science and Education 8(1): 1-8.

Handoyo, A. (2020). Hand Sanitizer Sederhana untuk Cegah Virus Corona. [internet]. [diakses pada tanggal 4 September 2020]. Tersedia pada: http://lipi.go.id/siaranpress/Hand-Sanitizer-Sederhana-untuk-CegahVirus-Corona/21970.

Kurniadi (2020). Pendampingan Pembuatan Hand Sanitizer Bentuk Pengabdian Kepada Masyarakat Tim Prodi Farmasi FK Untan. [internet]. [diakses pada tanggal 4 September 2020]. Tersedia pada: https://www.untan.ac.id/pendampingan-pembuatan-hand-sanitizerbentuk-pengabdian-kepada-masyarakat-tim-prodi-farmasi-fk-untan/

Larasati, A. L. and C. Haribowo (2020). Penggunaan Desinfektan dan Antiseptik Pada Pencegahan Penularan Covid-19 di Masyarakat. Majalah Farmasetika 5(3): 137-145.

Lestari, P. M. and A. Pahriyani (2020). Pelatihan pembuatan hand sanitizer perasaan buah jeruk nipis bagi guru, siswa siswi SMA dan SMK Mutiara 17 Agustus Kelurahan Teluk Pucung Bekasi Utara. SEMAR (Jurnal IImu Pengetahuan, Teknologi, Dan Seni Bagi Masyarakat) 7(1).

Novyana, R. M. and S. Susianti (2016). Lidah Buaya (Aloe vera) untuk Penyembuhan Luka. Jurnal Majority 5(4): 149-153.

Rahardjo, M., et al. (2017). Uji aktivitas antibakteri ekstrak etanol lidah buaya (Aloe vera) terhadap bakteri Staphylococcus aureus." Jurnal Kedokteran Syiah Kuala 17(2): 65-70.

Sadino, A., Destriani, Faradila, Fauziah, Hikmah, Meilani, Shofwa, Hartini Susi (2021). Penyuluhan dan Edukasi Perilaku Hidup Bersih dan Sehat sebagai Langkah Pencegahan COVID 19. J-ABDIPAMAS (Jurnal Pengabdian Kepada Masyarakat) 5(2): 169-174.

Sadino, A., Sahidin, Idin, Wahyuni, (2018). Antibacterial Activity of Polygonum pulchrum Blume Ethanol Extract on Staphylococcus aureus and Escherichia coli. Pharmacology and Clinical Pharmacy Research 3(2): 26-32.

Syapitri, H., Siregar, Laura Mariati Saragih, Frida Liharis (2020). Pencegahan Penularan Covid-19 Melalui Sosialisasi Dan Pembagian Masker Di Pasar Pringgan Medan. Jurnal Kreativitas Pengabdian Kepada Masyarakat (Pkm) 3(2): 422-429.

Walidah, I., et al. (2014). Daya Bunuh Hand Sanitizer Berbahan Aktif Alkohol 59\% dalam Kemasan Setelah Penggunaan Berulang terhadap Angka Lempeng Total (ALT). Jurnal Teknologi Laboratorium 3(1): 7-12. 